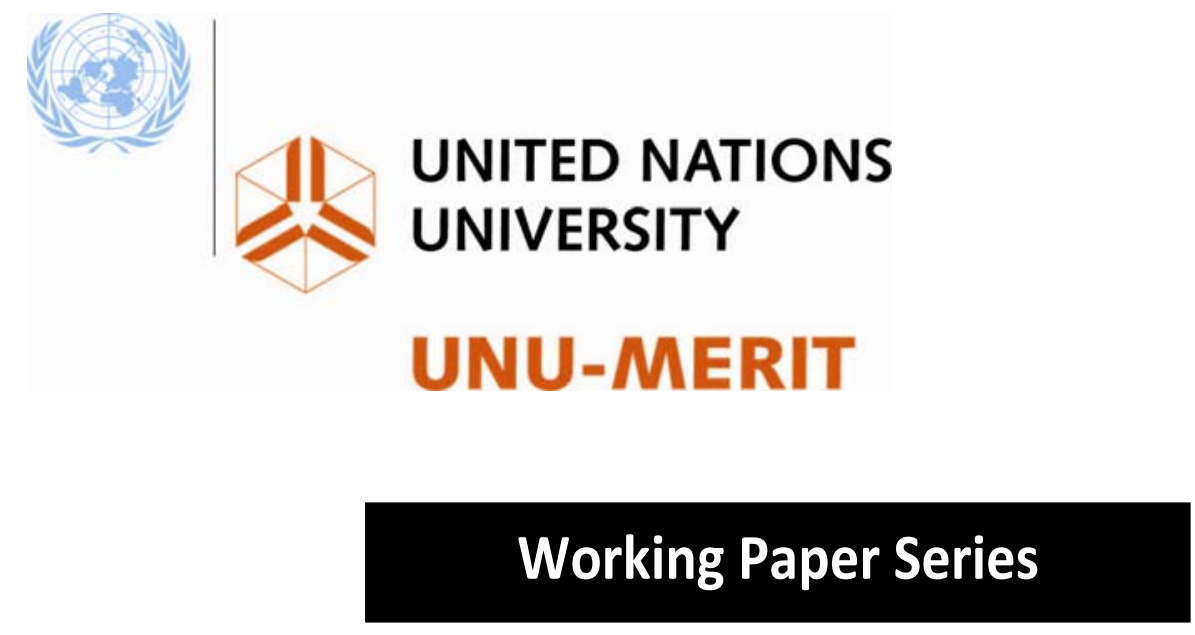

\#2013-034

\author{
Foreign direct investment as a driver of industrial development: \\ why is there so little evidence? \\ Rajneesh Narula
}

Maastricht Economic and social Research institute on Innovation and Technology (UNU-MERIT) email: info@merit.unu.edu | website: http://www.merit.unu.edu

Maastricht Graduate School of Governance (MGSoG)

email: info-governance@maastrichtuniversity.nl | website: http://mgsog.merit.unu.edu

Keizer Karelplein 19, 6211 TC Maastricht, The Netherlands

Tel: (31) (43) 388 4400, Fax: (31) (43) 3884499 


\section{UNU-MERIT Working Papers}

ISSN 1871-9872

Maastricht Economic and social Research Institute on Innovation and Technology, UNU-MERIT

Maastricht Graduate School of Governance

MGSoG

UNU-MERIT Working Papers intend to disseminate preliminary results of research carried out at UNU-MERIT and MGSoG to stimulate discussion on the issues raised. 


\title{
Foreign direct investment as a driver of industrial development: why is there so little evidence?
}

\author{
Rajneesh Narula
}

\begin{abstract}
This paper examines the role of FDI in promoting industrial development, and raises a rather important question: Why, if FDI is such an important avenue to promote development, is their little evidence on concomitant industrial development in most developing countries? This chapter takes a look at the evidence on FDI and development and explores some of the causes for this ambiguity. The complexities of global value chains and networks have begun to trivialize the simplistic principle that increased MNE activity automatically implies a proportional increase in spillovers and linkages. Policies towards MNEs need to be closely linked and integrated with industrial policy. MNE activity needs to be evaluated by considering the kinds of externalities that are generated; whether and how domestic actors can internalize them, and building up absorptive capacities to achieve this.
\end{abstract}

Keywords: MNEs, absorptive capabilities, motives, IDP, services, developing countries

JEL: F23, O14, O19

Forthcoming in: International Business and Sustainable Development, edited by Rob van Tulder, Alain Verbeke, Roger Strange, Emerald Publishing, 2014 


\title{
Foreign direct investment as a driver of industrial development: why is there so little evidence?
}

\author{
Rajneesh Narula
}

\section{Introduction}

Although today economists and policy makers in most countries consider the attraction and promotion of foreign direct investment (FDI) as a core aspect of their national development policies, this has not always been so. Indeed, in a relatively short time frame - less than 70 years - the importance of FDI to development has gone through several cycles. Prior to the 1950s, FDI was considered to be a temporary affair. Capital, moved from one country to another in response to medium-term differences in endowments, was considered to be part of the balance of payments, rather than a longer-term phenomenon. This is why, when we look at the International Financial Statistics published by the International Monetary Fund (IMF), FDI is still depicted as an annual flow, measured and understood in much the same way as trade. Indeed, even today, few countries bother to collect data on FDI flows beyond this mandatory (and rather superficial) reporting requirement to the IMF. With few exceptions, prior to the 1950s, the effects of FDI and its potential influence on either the host or home economy was largely ignored. Indeed, this is reflected in the lack of academic interest in the subject. Long-term capital flows were small and insignificant, and multinational enterprises (MNEs) were considered to establish foreign subsidiaries largely to support their trading activities, and such firms that engaged in more complex cross-border activities were a minor exception, deemed unworthy of serious analysis.

Even after the World War II era, few countries made an effort to estimate the size and significance of cross-border long term capital movements, with the possible exception of the UK and the USA, which engaged in systematic surveys of MNE activity relatively early. One might have thought that other large outward investors - France and The Netherlands come to mind -would have some interest in systematically documenting the scale and scope of the growing outward role of their large firms. Nonetheless, a majority of countries continued to produce rather rudimentary statistics (again, largely reflecting their obligatory reporting requirements to the IMF). Indeed, estimates of FDI stocks, sales, employment, and value added were more often than not estimated through indirect means, often reliably. The point remains, however, that the role of the MNE was rather small. By 1960, worldwide FDI stocks were estimated to be $\$ 55$ billion, an annual average growth rate of 5.6 per cent since 
1938(Figure1).To put this into context, this is roughly equivalent to the global sales of an MNE such as IBM today.

*** Figure 1 about here $* * *$

From the 1960s, the significance of FDI in host economies increasingly became a matter of considerable concern, given the growing popular view of MNEs as one of the causes of economic backwardness of the developing world. MNEs were increasingly regarded as political and economic agents of their home countries - a form of neo-colonialism. These were built around economic and political doctrines that drew their inspiration in some instances from Marxist rhetoric (which was developed further in the writings of Rosa Luxemburg [Luxemburg, 1913]). The point was that large corporations had a tendency to act as monopolists and engage in regulatory capture where it provided an opportunity to increase rents. Other work - deriving from ideas championed by Raul Prebisch, Hans Singer and others - similarly highlighted the dangers of depending upon foreign markets and foreignowned firms. They emphasized the importance of local, domestic companies in building up industrial production capacity. Set against the background of the cold war, and the dominance of US firms in Latin America, this played a significant role in the import-substitution ideas that were systematically adopted, first in Latin America, and later in most other developing countries. Nonetheless, even as these policies were systematically implemented in a growing number of economies, there was little attempt to document the role of MNEs in any serious empirical way by collecting data, whether on a firm, industry or country level, beyond some rather cursory (but alarming and rather important) case studies where MNE activity impeded development.

However, by the late 1970s, the pendulum began swinging in the other direction. To some extent, this reflected the failure of the developing countries to exploit the potential that was implied by import-substitution as a force for industrial and economic development. Few developing countries employing import-substitution policies had developed any significantly improved levels of industrial capacity, and those that had developed nascent industrial competences found it hard to sustain this capacity without distorting markets through large and inefficient interventions through public sector ownership and subsidies of various types that required large amounts of capital. Gradually, a number of these countries began seeking financial assistance from the World Bank, the IMF and private capital markets. These loans 
were conditional on implementing structural adjustment programmes which required them to become more 'FDI- friendly' and outward-oriented. This gradual opening up of the developing countries and shift away from import-substitution towards more open economic and capitalism-friendly policies was marked by a growing role of MNEs in developing countries, and indeed, in the developed countries that has adopted similar approaches. The amount of FDI stock had increased from \$166 billion in 1973 to 552 billion in 1983, and has since continued to increase at a rapid pace (Figure 1).

Outward oriented, export-promoting and FDI friendly policy regimes have gradually become the norm, and by the early 1990salmost all developing countries (and the countries from the communist bloc) had adopted such policies. Indeed, the GATT agreements, which originally focused primarily on trade issues had moved slowly towards embracing FDI issues, and have become an integral part of the WTO agreements that have succeeded GATT. Almost all supranational organisations including the World Bank, WTO, OECD and the UN are now keen to promote the concept that FDI was a sine qua non for economic development, and almost all developing countries had adopted such polices.

Despite FDI becoming a centrepiece of development policy, and FDI-assisted development becoming the new dogma, the evidence on FDI-assisted economic development in developing countries remains ambiguous. This chapter takes a look at the evidence on FDI and development and explores some of the causes for this ambiguity.

\section{Understanding FDI and development}

Perhaps the simplest way of explaining the challenges of development is the idea of the vicious cycle of poverty (VCP). The principle of the cycle of poverty is that poverty can be a self-perpetuating problem that requires intervention of some nature. Poverty and underdevelopment are, for all intents and purposes, synonyms (poverty is at the smallest unit of analysis: the individual. Under-development concerns societies, which are by definition an aggregation of individuals). The term 'vicious' emphasizes the challenges of extrication, and the fact that there is a self-perpetuation of a negative set of associations. What the VCP illustrates is the bottom -up interrelationship between economic condition of the individual and the society in which she is embedded. Figure 2 demonstrates a very simplified (and stylized) version of the VCP. 
*** Figure 2 about here $* * *$

Essentially, a country that is underdeveloped and suffers from high levels of poverty also has low levels of employment. Low levels of employment means that aggregate income is low, and with the average individual income levels being close to (or below) the poverty line, there is little opportunity for savings by individuals. This implies that there is little liquidity within the economy, and banks - which rely on savings to make loans to industry or entrepreneurs - are unable to lend money to potential employers (i.e., firms). Thus start-ups cannot find capital, and established firms will be unable to expand. Besides, since capital is scarce, whatever capital is available is only be at high interest rates. Thus, there will be little expansion of domestic industry, and employment levels will remain low, thereby perpetuating the cycle of poverty.

\section{***FIGURE 2 ABOUT HERE***}

This idea forms the basis of most development models. In particular, the free market view is that if capital were made available both easily and cheaply- through, for instance, an influx of capital from foreign lenders, aid, and remittances - entrepreneurs and businesses might have the opportunity to grow, thereby increasing employment, which in turn would increase incomes, raise saving rates, and thereby increase liquidity, which in turn would lead to more liquidity, etc., breaking the cycle of poverty.

Of course, making capital more freely available helps to improve things marginally. Making capital more easily available - for instance through micro lending - addresses some of the problems of poverty and underdevelopment, but it fails to address the bigger question of creating and sustaining development at the larger level. It may create some additional employment and result in higher individual incomes at the margin, but it does not begin a shift from subsistence activities (typically associated with the agricultural sector) to structured and formal economic activities, and simple capital infusions are not a pervasive or sustainable solution to growth. It is one thing to have capital, it is entirely another to be able to utilize it to generate a sustained return on this capital. This presumes some sort of ownership advantages, either in terms of knowledge of markets, skills, technology, or management abilities on the part of the entrepreneur. Despite large flows of foreign remittances to countries such as Pakistan, India, Nigeria, the growth of firms in the formal sector remains low. 
Promoting industrialisation - as opposed to small scale entrepreneurship - depends on firms (as opposed to entrepreneurs with capital) access to some kind of technology, managerial skills, and so forth, not just liquidity. Firms (and individuals) need to have access to some form of knowledge-based assets from which they can generate profits. Such assets are not as easily acquirable on the open market. Simply buying the equipment and technology required to build a car factory, for instance, is insufficient to create a commercially and technologically successful product. It is easy to illustrate this with the failure of the Soviet automobile industry. Or indeed, India's attempt at building cars from the 1950s, built around two imported designs. In both the Soviet and Indian cases, the car plants were turnkey projects, but the domestic firms were unable to make a competitive product, because they lacked either the organisational and technological expertise, or the managerial and marketing skills needed.

Earlier models of development - popular and prevalent in the 1950s and 1960s - were built on the assumption that such knowledge based assets were relatively easy to acquire. Indeed, these were made available through various technology transfer programmes that were promoted by bilateral programmes and development agencies. Arms-length arrangements to license technologies and turnkey projects (i.e., large projects built by a foreign firm, which were later transferred to domestic ownership) were made available with the idea that domestic firms would easily be able to internalize these assets and technologies, and eventually be able to imitate (and upgrade) them, thereby being able to compete with foreign (developed country) competitors. It is no surprise that many of these grand projects instituted to transfer technology largely failed. We should note, of course, that some of these failures occurred because many such projects were 'prestige' projects which were entirely inappropriate for the host countries, but selected simply because they met the grandiose expectations of various political groups.

This model, therefore, made capital and technology available separately, but little account as taken of the cost (and time) of transferring skills and expertise to domestic workers, entrepreneurs and firms. Although training programmes were established, the assumption was that technology (and managerial know-how) was an easily-transferable good, greatly underestimating the tacit aspect of knowledge. This was especially a challenge with the more technology-intensive sectors: the more complex the technology, the greater the tacit element, thereby making its transfer more difficult. The difficulty of transferring technology applies not just to machinery and equipment but also the 'soft' aspects or organising and operating a 
business, such as finance, human resource and general management.It did not help that many countries also decided to rely on state-owned enterprises and large projects that were on a scale completely unsuited to the local economy. That is, building an automobile industry whose minimum efficient scale is 250,000, where annual demand was less than a 100,000 almost guaranteed that the unit costs would be substantially higher than similar imported products. Projects were also sometimes located in response to political objectives, rather than on economic ones. As an example, steel rolling mills in Nigeria were located almost a 1000 $\mathrm{km}$ away from where the pig iron was smelted, with no proper transport links between the two sites, entirely because it was politically expedient to do so. This immediately ensured that steel was produced at uncompetitive prices, and without high import tariffs and subsidies, the domestic sector was unable to survive. Similar examples exist in almost every developing country where attempts to break the cycle of poverty through separate 'injections' of capital and technology did not work, with rather few exceptions. These exceptions mostly reflected situations where government planners sought to match the industrial projects to the competences and resources of the economy in which they were established.

It was against this backdrop of failed large-scale interventions that the idea evolved that there were considerable potential benefits from using MNEs to break the cycle of poverty and build domestic capacity. FDI represented a 'package' of both capital and technology. The MNE already possessed the appropriate machinery and equipment, as well as the engineering skills to utilize this equipment efficiently, not to mention the managerial expertise needed to organize these activities to generate a profit. Their choice of products and processes was based on economic reason and rationale, rather than on prestige and political objectives. In most cases, they exploited technologies that were most suitable for the location, rather than the latest technologies that were inappropriate for the comparative advantages of the host economy.

This is the principle - in a very broad sense - that FDI-assisted industrial development has been based on. The growth of FDI over the last 30 years, and the increasingly popular use of industrial policy that relies on MNEs reflect this particular model for economic growth through industrial development. However, it is not always clear that this model works. The next section explores some of the challenges in this regard.

\section{Why does FDI-assisted industrial development not always work?}


Despite the fact that FDI-assisted industrial development is now the new dogma, itis not entirely clear that greater FDI has caused more rapid development. Why is that?

Quantitative researchers have often made the rather simple error of concluding that because FDI levels and GDP growth are highly correlated, there must be causality (for a discussion, see e.g., Chowdhury and Mavrotas (2006), Hansen and Rand (2006)). The more skeptical view is that the determinants of GDP growth happen to be the same as the determinants of increased inward FDI flows, but a kinder interpretation is that there is an important concatenation between the two. Simply put, MNE (or FDI) activity is not a condition sine qua non for development (Lall and Narula 2004). Instead the link between MNEs and development is an indirect one: Where inward MNE activity results in positive externalities, and when domestic firms have the capacity to usefully internalize these externalities, and if the non-firm sector supports domestic capacity building, there will be industrial development (Narula and Dunning 2010).Second, there is a fundamental error on the part of analysts that every dollar of FDI has the same potential to promote development. The evidence is clear that not all FDI is equal in this regard: certain investment projects simply have a higher multiplier effect than others. In brief: not all FDI is the same from its value to development, and this itself is a function on the level of economic development of the country (Dunning and Narula 1996). Both of these arguments are broad issues, and one that I cannot hope to cover in sufficient detail in a single chapter. However, I offer some indicative comments on both here. It is also worth highlighting that the two issues are connected. I have emphasized elsewhere the importance of 'the right kinds' of FDI (Narula and Dunning 2000). This is itself dependent on the kinds of L advantages available to the MNE. Even where the 'right kinds' of MNE activity are located in the host country, the ownership advantages of domestic firms need to have the necessary absorptive capability to benefit from them.

\section{Not all FDI is equal: the heterogeneity of MNE motivations}

Considerable differences have emerged over the last 40 years, as MNEs have evolved in their spatial and internal organization of their activities. MNE activity was primarily driven by cost-economizing considerations as well as efforts to overcome market failures to trade. Cross-border organization structures were simple, and motivations for specific subsidiaries tended to be overwhelmingly resource seeking or market-seeking, with a minority of MNEs engaged in efficiency-seeking or strategic asset-seeking activities. The emphasis has shifted considerably over the last 30 years, in that MNEs have become increasingly sophisticated in 
managing and integrating activities across borders, and even relatively new and smaller MNEs are organized to maximize cross-border efficiencies and take advantages of the economies that derive from multinationality.

It is generally acknowledged that there are four main motives for investment: to seek natural resources; to seek new markets; to restructure existing foreign production through rationalization, and to seek strategically related created assets. These in turn can be broadly divided into two types. The first three represent motives which are primarily asset-exploiting in nature: that is, the investing company's primary purpose is to generate economic rent through the use of its existing firm-specific assets. The last is a case of asset-augmenting activity, whereby the firm wishes to acquire additional assets which protect or augment their existing assets in some way. Broadly speaking, FDI to most developing countries tends to be focused on asset exploitation. MNEs seek to benefit from globalization by leveraging their assets (whether in terms of exploiting economies of scale or scope) to supply a wider array of markets in a broader set of countries.

Although there has been growth in FDI in developing countries, it is worth noting that different motives of FDI provide different potential for domestic spillovers and linkages. There are two areas where a large share of the growth in FDI to developing countries has come from: resource-seeking FDI and services FDI. That is to say, a very large share of FDI has been in resource-extracting sectors (such as mining and petroleum), and the tertiary sector, and not in the manufacturing, where past research has indicated a greater potential for linkages and spillovers to the domestic industry. Services FDI in developing countries increased by a factor of eight between 1990 and 2004, twice that of FDI stocks in manufacturing. FDI in the primary sector also grew 50 per cent faster during the same period.

One of the primary changes associated with the WTO (and in general, from economic liberalization) has been the ability of MNEs to engage in the services sector. In many cases, the services industries in developing countries were dominated by large state-owned enterprises that were often inefficient, but enjoyed a local monopoly. Liberalization led to the privatization of many of these firms, often by much more efficient MNEs. However, it is not immediately clear that these investments have the same effect on domestic entrepreneurship and employment.- investments in telecommunications (for instance) provides relatively few knowledge spillovers and linkages to domestic firms in the least developed countries, compared to (say) manufacturing, although there may be pecuniary spillovers. In other 
sectors, such as transportation, banking and insurance, the benefits have been limited in terms of creating and promoting domestic firms as suppliers or competitors, such as in Insurance, banking, where MNEs enjoy important benefits of size and multinationality. FDI in services may have a profound competition effect and increase the consumer surplus, but it does not always create linkages and potential for technological upgrading by domestic firms.

Likewise, there has been considerable growth in FDI in the primary sector in many developing countries. However, large amounts of FDI to resource-rich economies such as Nigeria, South Africa and so on, have not always resulted in building up domestic capacity. In general, natural resource-extractive FDI tends to have limited opportunities for employment. These activities also do not provide opportunities for significant knowledge transfers and on the whole cannot be expected to provide significant spillovers and linkages (Morrisey 2010, 2012). Resource-seeking investment generally (but not always) implies lowvalue adding activity and low capital expenditure on plant and equipment (extractive industries being the exception), FDI is less 'sticky', i.e., more footloose. In general, a purely resource-seeking investment is not normally tightly integrated into the investing firm's organizational structure: indeed MNEs rarely engage in complete internalization of raw material markets; they prefer instead to conclude non-equity agreements with foreign firms, or purchase their inputs at arm's-length prices. In general, FDI in the least developed countries is often largely resource seeking. Since -least-developed countries tend to have few location advantages to offer MNEs beyond natural resources, this is often the only kind of FDI present. Where vertical forward integration and further value adding does occur, either to exploit markets or to access other location advantages, the 'stickiness' of the investment increases.

\section{The absence of absorptive capacity}

Even where the motivation of MNE activity creates opportunities for spillovers and linkages to the host economy, it is not always the case that the domestic economy has the capacity to absorb them. Even where the 'right kinds' of MNE activity are located in the host country, domestic firms need to have the necessary absorptive capability to benefit from them.Absorptive capacity has been more extensively analysed at the firm level, where technological learning and technological change take place, and where available data have allowed researchers to assess the role of absorptive capacity in the firm's innovation 
performance (Cohen and Levinthal 1989, 1990). In their 1989 article, Cohen and Levinthal define absorptive capacity as “the firm's ability to identify, assimilate, and exploit knowledge from the environment”. It is important to note that absorptive capacity is a subset of technological capability, which in addition to absorptive capacity includes the ability to generate new technologies through innovative means.In order to understand the notion of national absorptive capacity one should keep in mind that a country's absorptive capacity is not simply an aggregation of its firms or its industries. It is salient to point out that firms operate within systems and countries, like firms, are not isolated from outside knowledge. Hence, absorptive capacity may be affected by the stock of knowledge of firms of other countries (Criscuolo and Narula 2008).

Much of the work on absorptive capacity considers the primary determinant behind technological accumulation and absorptive capacity in countries as human capital. Indeed, the definition of human capital shares much with absorptive capacity and several empirical studies have in fact used human capital measures as proxies for absorptive capacity. Both human capital and absorptive capacity involve learning activities and therefore are cumulative processes: The competence “...to evaluate and utilize outside knowledge is largely a function of the level of prior related knowledge” (Cohen and Levinthal, 1990: 128). Qualified human resources are essential in monitoring the evolution of external knowledge and in evaluating their relevance, and for the integration of these technologies into productive activities.

The availability of a large stock of suitably qualified workers does not in itself result in efficient absorption of knowledge, as is well illustrated by the former socialist economies of Eastern Europe (Narula and Jormanainen 2008). Absorbing and utilising knowledge that is embodied in MNEs and their products, services, and activities requires the existence of firms and other economic actors, which in turn requires the presence of institutions for them to function efficiently. As mentioned earlier, economic actors - whether firms or state actors need also to be able to efficiently utilize markets and hierarchies, be they intra-firm, intraindustry or intra-country. This knowledge is not costless, and must be accumulated over time. Important externalities arise which impinge on the ease of diffusion and efficiency of absorption and utilization of external knowledge.

Absorptive capacity is therefore also concerned with the efficient use of knowledge acquired. Firms need the ability to use prior knowledge in the solution of practical problems that are 
commercially viable. Thus, absorptive capacity implies problem-solving skills that emerge directly as a result of attempts to assimilate external knowledge(Criscuolo and Narula 2008).

Absorptive capacity also reflects the ability of a country to integrate the existing and exploitable resources - technological opportunities - into the production chain, and the foresight to anticipate potential and relevant technological trajectories. This ability is therefore affected by the international technological environment. The extent to which a firm is able to exploit external sources of knowledge thus depends on its absorptive capacity, which is assumed to be a function of its innovative efforts and the degree to which outside knowledge corresponds to the firm's needs, as well as the general complexity of the knowledge target.

For FDI-assisted development to occur, it is important that a minimum level of absorptive capacity exists. The existence of an external stock of knowledge (in the form of FDI) does not automatically imply efficient internalization by domestic firms, because knowledge can be specific to the originating source. Hence, a country (and by extension, its firms and its entrepreneurs) should possess a minimum threshold stock of knowledge that will allow it to absorb external knowledge. Successful absorption should lead to higher productivity growth. Narula and Marin (2003) show that only firms with high absorptive capacity are likely to benefit from FDI spillovers. Likewise, Xu (2000) shows that a country needs to reach a minimum human capital threshold level in order to benefit from technology transfer. The absence of sufficient levels of absorptive capacity tends to lead to the inefficient use of technology flows that occur through FDI.

The ambiguous empirical evidence on the impact of FDI at the host country level reinforces the claim that MNE externalities and knowledge spillover effects are not automatic as one would tend to believe but are affected by several host-industry and host country factors. An important characteristic for the emergence of technology spillovers is the technology gap between MNE affiliates and local firms in the host country. There is evidence to support the hypothesis that spillovers are easier to identify empirically when the technological attributes of local firms match those of the MNE affiliates. Kokko et al (1996) argue that a high technology gap combined with low competition prevents spillovers to the host economy. The absorptive capability of host country firms to absorb foreign technology appears to be an important determinant of the size of the FDI spillovers. Kokko et al. (2001) also highlight the importance of past experience in industrialisation as a precondition for international transfer 
of technology and the absence of this experience is concomitant to lack of absorptive capacity by the local sector (Radosevic 1999). For example, in the Sub-Saharan African region the conditions that stimulate technological assimilation (such as developed human capital, adequate physical infrastructure and a dynamic business climate) are absent, leading to constraints in mastering foreign, imported technology as well as to compete in international markets (Mytelka 1985, Lall and Pietrobelli 2002). The development of domestic capacities and capabilities is key to both potentially attracting more FDI inflows as well as increasing the potential for MNE technological spillovers tenable to industrial upgrading of the host economy.

It is unfortunate that most FDI policies of developing countries focus almost exclusively on the attraction of FDI, as if it were simply a matter of capital, rather than systematically engaging the MNEs to achieve greater embeddedness.

The changing nature of the MNE and its relationship to FDI

FDI and MNE activity have been synonymous, partly a reflection of the way in which most international and national agencies that maintain and collect data on MNE activity. Although FDI remains one of the main modes by which MNEs engage in cross-border value adding activities, the MNE may also control and engage in value adding activities through nonequity means, such as through cooperative agreements and outsourcing, sometimes without de jure ownership of the productive assets, but de facto controlling the operations of the nonaffiliated operation. Therefore, the use of the term 'MNE' as a synonym for FDI is increasingly inaccurate (Narula and Dunning 2010). There is no clear estimate of the value of 'non-FDI' component of MNE activity, but it may be as high as a one-third of the FDI component.

When we raise the discussion to the level of the MNE, the significance of the physical establishment takes a less important role. We discuss this concept using Figure 2, which shows using a two-country scenario and is based around a joint venture between an MNE and a domestic firm. MNEs engage in a variety of other agreements, many of which use a variety of means to engage in knowledge exchange. For instance, technology may be licensed or purchased by the MNE affiliate from unaffiliated public research organisations either abroad or based locally. A second set of linkages are active two-way collaborations (indicated in figure 3 by the dashed lines which may involve a large array of actors, both domestic and foreign. Such agreements represent a higher level of knowledge exchange, and may be 
undertaken with a variety of partners. In general, these non-equity linkages present considerable potential to increase knowledge flows and the potential technological competitiveness of domestic firms, as it creates important new sources of demand for commercially driven economic units engaged in R\&D.

*** FIGURE 3 ABOUT HERE ***

\section{$\underline{\text { Not all affiliates are created equal }}$}

The nature of the affiliate and the nature of their role within the MNE's global portfolio of affiliates play a significant role as well. Some affiliates may be passive in the sense that they may receive ready-made innovations from their parent firms. Thus, they do not establish these other types of linkages that might enhance the indigenous innovation milieu. In other words, at one extreme, the affiliate may be operating in an enclave, utilising foreign suppliers and foreign collaborators that have been pre-specified by their parent firm. Such affiliates are largely unassimilated with the host country innovation system, although they may engage in value adding activity and be part of business systems in the host country, and may have spillovers in terms of low-level employment, etc.

*** FIGURE 4 ABOUT HERE ***

The quality of the knowledge spillovers that derive from an investment are associated with the scope and competence level of the subsidiary, and these are co-determined by a variety of factors (see figure 4). These include MNE internal factors such as their internationalization strategy, the role of the new location in their global portfolio of subsidiaries, and the motivation of their investment, in addition to the available location-specific resources which can be used for that purpose (Benito et al 2003). High competence levels require complementary assets that are non-generic in nature and are often associated with agglomeration effects, clusters, and the presence of highly specialized skills (Lall and Pietrobelli 2002). In other words, firms are constrained in their choice of location of high 
competence subsidiaries by local resource availability. For instance, R\&D activities tend to be concentrated in few locations, because the appropriate specialized resources are associated with only few locations. The embeddedness of firms is often a function of the duration of the MNEs' presence, since firms tend to build incrementally. However, while the scope of activities undertaken by a subsidiary can be modified more or less instantly, developing competence levels takes time. MNE investments in high value-added activities (often associated with high competence levels) have the tendency to be 'sticky'. Firms demonstrate greater inertia when it comes to relocating R\&D activities (Narula, 2002).

*** FIGURE 4 ABOUT HERE ***

Increasingly firms are engaged in rationalising their activities globally, so as to maximize the link with specific value adding activities and locations which have specific competitive and comparative advantages. This has led to a tendency amongst MNEs to 'break-up' their value chains and locate specific aspects in particular locations for purposes of maximum efficiency. As such, few locations host all parts of the value chain of one product for any give MNE, leading to an agglomeration of specific types of activities in particular locations. Prior to economic liberalization, MNEs responded to investment opportunities primarily by establishing truncated miniature replicas of their facilities at home, although the extent to which they are truncated varied considerably between countries. The extent of truncation was determined by a number of factors, but by far the most important determinant of truncation and thereby the scope of activities and competence level of the subsidiary - were associated with market size, and capacity and capability of domestic industry (Dunning and Narula 2004).

\section{*** FIGURE 5 ABOUT HERE ***}

One of the results of globalisation and the subsequent spatial redistribution of their value chains has been that many countries have seen a downgrading of their subsidiaries in terms of scope and competence, moving towards sales and marketing operations, although some rather few - locations have seen a reduction in the cope, but an increase in the competence levels towards R\&D units. Only very few have seen a shift towards strategic centres, or indeed maintained a multi-activity unit. 
As firms have used global production networks, this has by and large been to the benefit of the MNE, while most host countries with generic location advantages have seen a shift in scale, scope and competence. The competition for such activities between locations is considerable, and few locations provide the specialized and well-developed innovation systems that are needed. The benefits from subsidiaries vary considerably. A sales office or an assembly unit may have a high turnover, employ a large staff, but the technological spillovers will be relatively fewer than, a manufacturing facility. Countries that are at an early stage of development with a very limited domestic sector are often host to single-activity subsidiaries, primarily in sales and marketing, as well as natural resource extraction. The most advanced economies with domestic technological capacity have hosted the least truncated subsidiaries, often with R\&D departments.

Few MNEs still utilize miniature replicas when engaging in Greenfield investments. Rationalisation of activities within the single market has, in many cases, led to a downgrading of activities from truncated replica to single activity affiliates. MNEs have taken advantage of the globalisation to rationalize production capacity in fewer locations to exploit economies of scale at the plant level, especially where local consumption patterns are not radically different to justify local capacity and where transportation costs are not prohibitive. This has meant that some miniature replicas have been downgraded to sales and marketing affiliates, which can be expected to have fewer opportunities for spillovers.

\section{Discussion and implications for theory and policy}

This chapter examines the role of FDI in promoting industrial development, and raises a rather important question: Why, if FDI is such an important avenue to promote development, is their little evidence on concomitant industrial development? There are well over 150 countries that are classified as 'developing', yet over 50 per cent of the FDI stocks in the developing world are based in less than 10 countries. As Table 1 shows, there is a high concentration of FDI in just a few countries. Indeed, in each continent, a handful of countries account for the majority of MNE investments.

\section{*** Table 1 ABOUT HERE ***}

To some extent this reflects the fundamental dynamics of the investment development path. The level and extent of MNE activity into and from every country reflects the underlying 
economic structure and level of development of each country. Figure 6 illustrates the fundamental dynamics of the IDP, which has become a popular tool for analysing the interaction between FDI and development.

Despite the apparent graphical simplicity of the IDP, it hides a variety of complex and important assumptions and generalisations, which have been discussed at length in Narula and Dunning (2010). At one level, however, the IDP remains valid in its most basic role: that of understanding that growth of countries and the growth of the commercial activity of domestic and foreign firms are closely linked together. It also still remains the case that countries' location assets and the ownership advantages of its firms reflect the sequential

processes associated with other, similar countries. Few countries behave atypically. For instance, it is rare to see low-economic-stage countries generating significant outward FDI as they do not have the absorptive capacity or the economic structure to support it (Narula 2012). Likewise, inward FDI does not simply rush into countries simply because there are incentives and subsidies without strong location advantages. As this paper (and many others) have emphasized, simply having FDI inflow does not automatically translate into economic growth for the recipient country.

*** FIGURE 6 ABOUT HERE ***

At the same time, this paper discusses the fact that the IDP hides many sins by being a macro-framework: FDI is no longer always a reliable proxy of MNE activity, and that different motives of FDI have different development outcomes. Besides, the economic structural evolution concept that has been the mainstay of the economic development community does seem to be coming apart: that countries sequentially evolve from primary to manufacturing to services, we have identified two of the reasons for this: the significant share of FDI going to the primary and tertiary sector; and the break-up of the value chain.

Quite apart from the dangers of crowding-out and the problems of stage-inappropriate MNE activities, it is not clear that increased MNE activity necessarily implies a proportional increase in spillovers and linkages. An important issue not dealt with in this chapter is the potential development effects of MNE activity in the services sector. This has been an area of growth in terms of inward FDI. However, there is considerable variety in the nature of services - investments in telecommunications provides relatively few knowledge spillovers 
and linkages to domestic firms in the least developed countries, compared to banking. To our knowledge, there are no studies that evaluate relative benefits of investments in tertiary sectors, relative to primary or secondary sectors.

Developing countries have largely liberalized their policies towards FDI, but this is not the same as developing FDI policies. Most take a passive approach to attracting FDI flows, and pay insufficient attention to the nature of the benefits and costs associated with embedding subsidiaries and exploiting externalities. The adoption of neoliberal policies as part of structural adjustment programmes in many developing countries has meant that few have an explicit or well-considered industrial policy, often applying principles that belong as part of a more closed, import-substituting era. This is increasingly at odds with the economic realities of a post-WTO, interdependent world. Specifically, policies towards MNEs need to be closely linked and integrated with industrial policy. MNE activity needs to be evaluated by considering the kinds of externalities that are generated; whether and how domestic actors can internalize them; and what kinds of $\mathrm{L}$ advantages may be required to achieve this. Indeed, the 'success stories' of MNE-assisted development have sought to attract MNEs, but have also built up domestic absorptive capacities in tandem. 
Benito, Gabriel, B. Grogaard and R. Narula (2003). "Environmental Influences on MNE Subsidiary Roles: Economic Integration and the Nordic countries”, Journal of International Business Studies,34, pp.443-456.

Chowdhury, A. and Mavrotas, G. (2006) FDI and Growth: What Causes What? World Economy, 29/1: 9-19

Cohen, W.M.; Levinthal, D. (1989). "Innovation and learning: The two faces of R\&D”, in The Economic Journal, Vol. 99, pp. 569-96.

Cohen, W.M.; Levinthal, D. (1990). “Absorptive capacity: a new perspective on learning and innovation”, in Administrative Science Quarterly, Vol. 35, pp.128-52.

Criscuolo, P. \&Narula, R.(2008) A novel approach to national technological accumulation and absorptive capacity: Aggregating Cohen and Levinthal, The European Journal of Development Research, 20(1), pp. 56-73.

Dunning, John H. and Rajneesh Narula (1996). Foreign Direct Investment and Governments: Catalysts for economic restructuring, Routledge, London and New York.

Dunning, John H. and Rajneesh Narula (2004).Multinational and Industrial Competitiveness: A New Agenda, Cheltenham: Edward Elgar.

Hansen, H and Rand, J (2006) On the Causal Links Between FDI and Growth in Developing Countries, World Economy, 29/1: 21-41

Kokko, A,,Tansini, R and Zejan, M. (1996). “Local technology capability and productivity spillovers from FDI in the Uruguayan manufacturing sector”.Journal of Development Studies, 32(4), 602-612.

Kokko, A., Zejan, M. and Tansini, R. (2001). “Trade Regimes and Spillover Effects of FDI: Evidence from Uruguay”, WelwirtschaftlichesArchiv, Vol. 137, pp. 124-149.

Lall, S and Pietrobelli, C. (2002), Failing to Compete. Technology Development and Technology Systems in Africa, Edward Elgar.

Lall, S. \&Narula, R. (2004) FDI and its Role in economic development: Do we need a new agenda, European Journal of Development Research, 16(3), pp. 447-464.

Luxemburg, R. (1913)The accumulation of Capital, London, Routledge.

Morrissey, O. (2010) 'Impact of China and India on SSA Countries', Trade Hot Topic Issue 80, London: Commonwealth Secretariat

Morrissey, O. (2012) FDI in Sub-Saharan Africa: fewer linkages, fewer spillovers, The European Journal of Development Research, 24 
Mytelka, Lynn K. (1985). “Stimulating Effective Technology Transfer: The Case of Textiles in Africa”, in Rosenberg, $\mathrm{N}$ and Frischtak, C. (eds.) International Technology Transfer, Praeger, New York. 1985.

Narula, R. (2002). Innovation systems and 'inertia' in R\&D location: Norwegian firms and the role of systemic lock-in, Research Policy, 31: 795-816

Narula, R. (2012) Do we need different frameworks to explain infant MNEs from developing countries? Global Strategy Journal, 2, 188-204

Narula, R. and Dunning, J. (2000). "Industrial development, globalisation and multinational enterprises: New realities for developing countries”, in Oxford Development Studies, Vol. 28, No.2, pp. 141-67.

Narula, R. and Marin, A. (2003).“FDI spillovers, absorptive capacities and human capital development: Evidence from Argentina”, MERIT Research Memorandum 2003-16.

Narula, R., Dunning, J. (2010) Multinational enterprises, development and globalisation: Some clarifications and a research agenda, Oxford Development Studies, Vol. 38, No. 3, pp. 263-287.

Narula, R., Jormanainen, I. (2008) When a good science base is not enough to create competitive industries: Lock-in and inertia in Russian systems of innovation, UNU-MERIT Working Paper Series 2008-059

Radosevic, Slavo, (1999). Transformation of science and technology systems into systems of innovation in central and eastern Europe: the emerging patterns and determinants., Structural Change and Economic Dynamics, Vol 10 (3-4), pp 277-320.

Xu, B. (2000). "Multinational enterprises, technology diffusion, and host country productivity growth”, in, Journal of Development Economics, Vol. 62, pp. 477-93. 


\section{Figure-1: Inward FDI stocks 1937-2010}

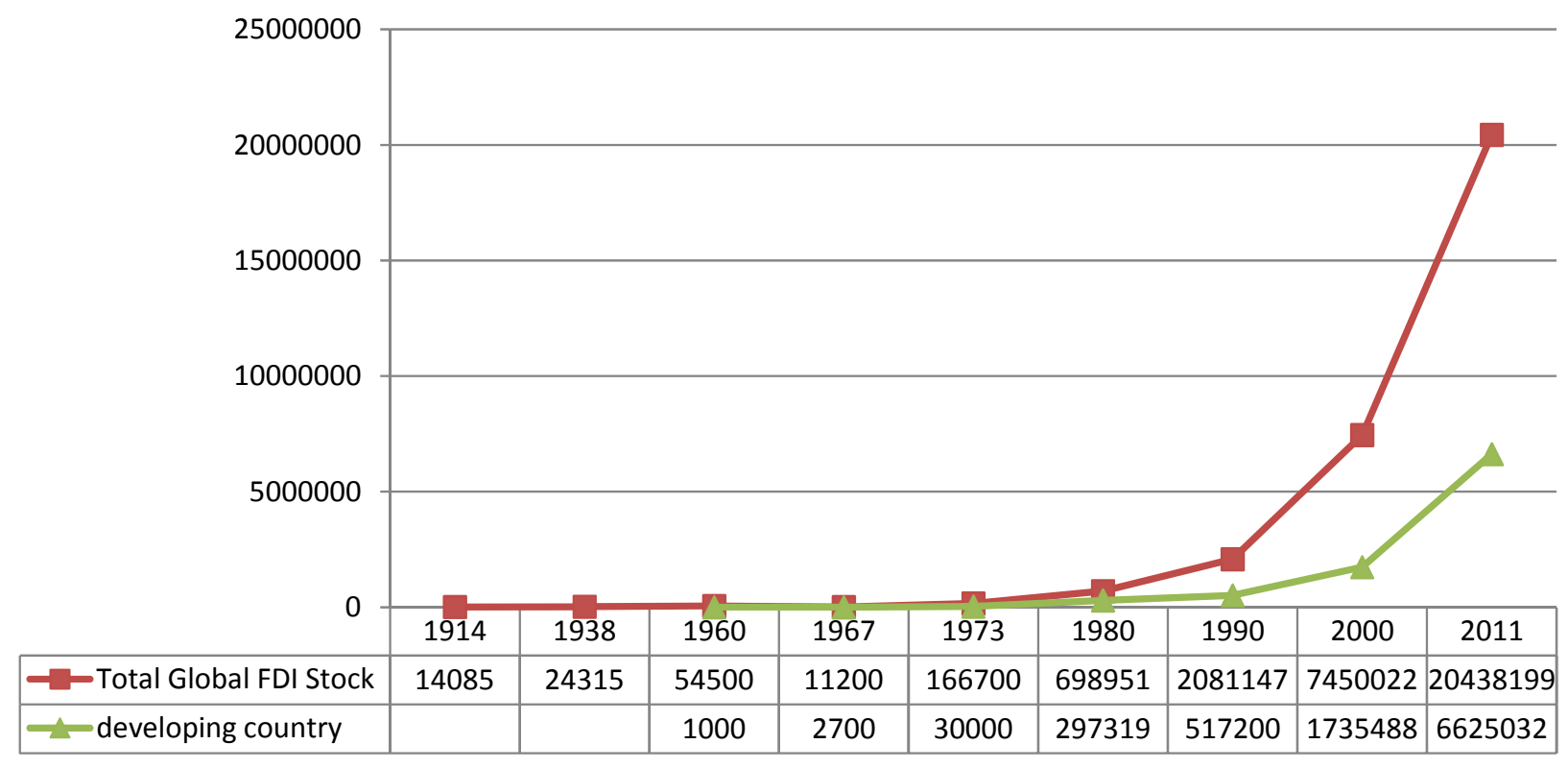

Source: UNCTAD World Investment Report 


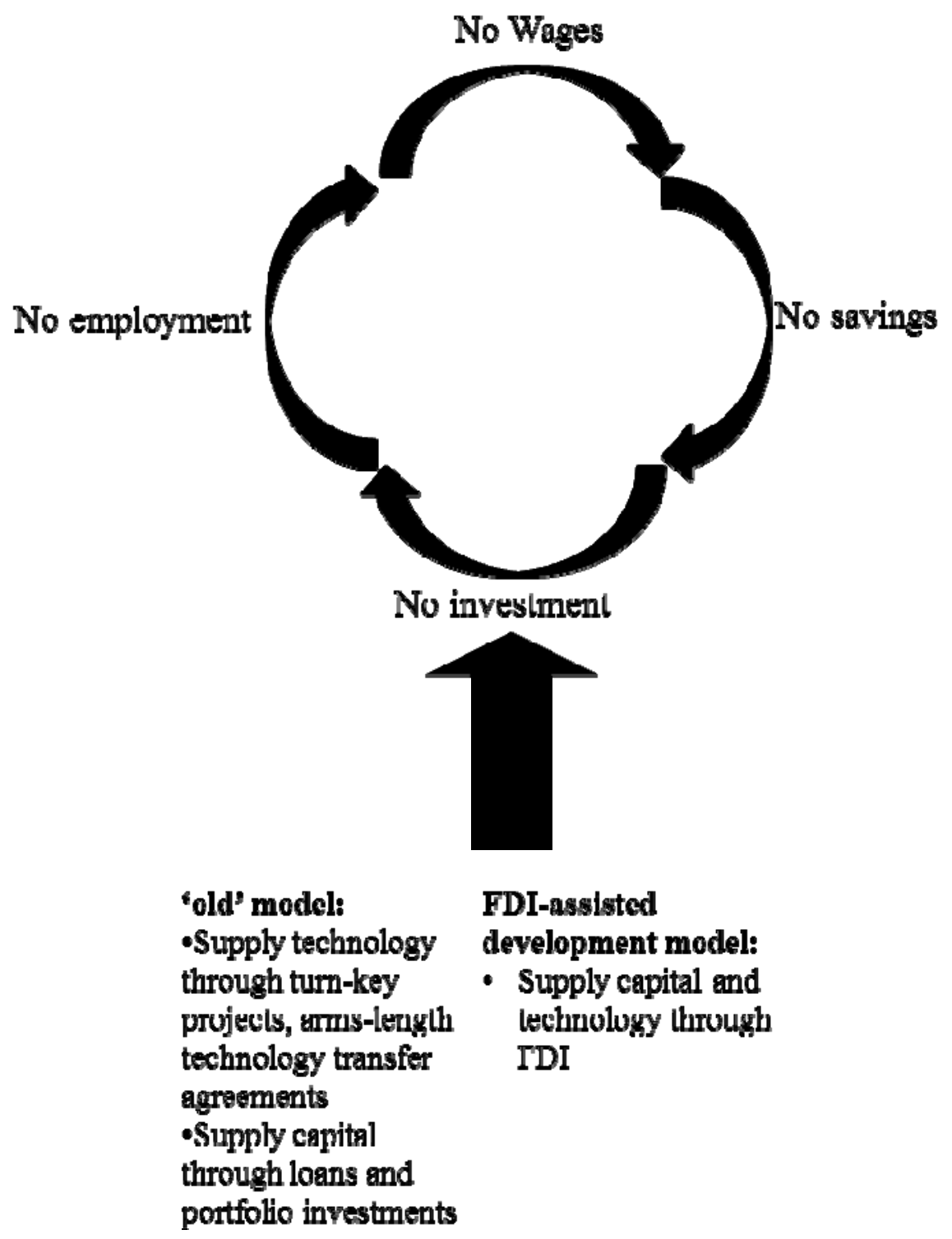

Figure 2: The vicious cycle of poverty 


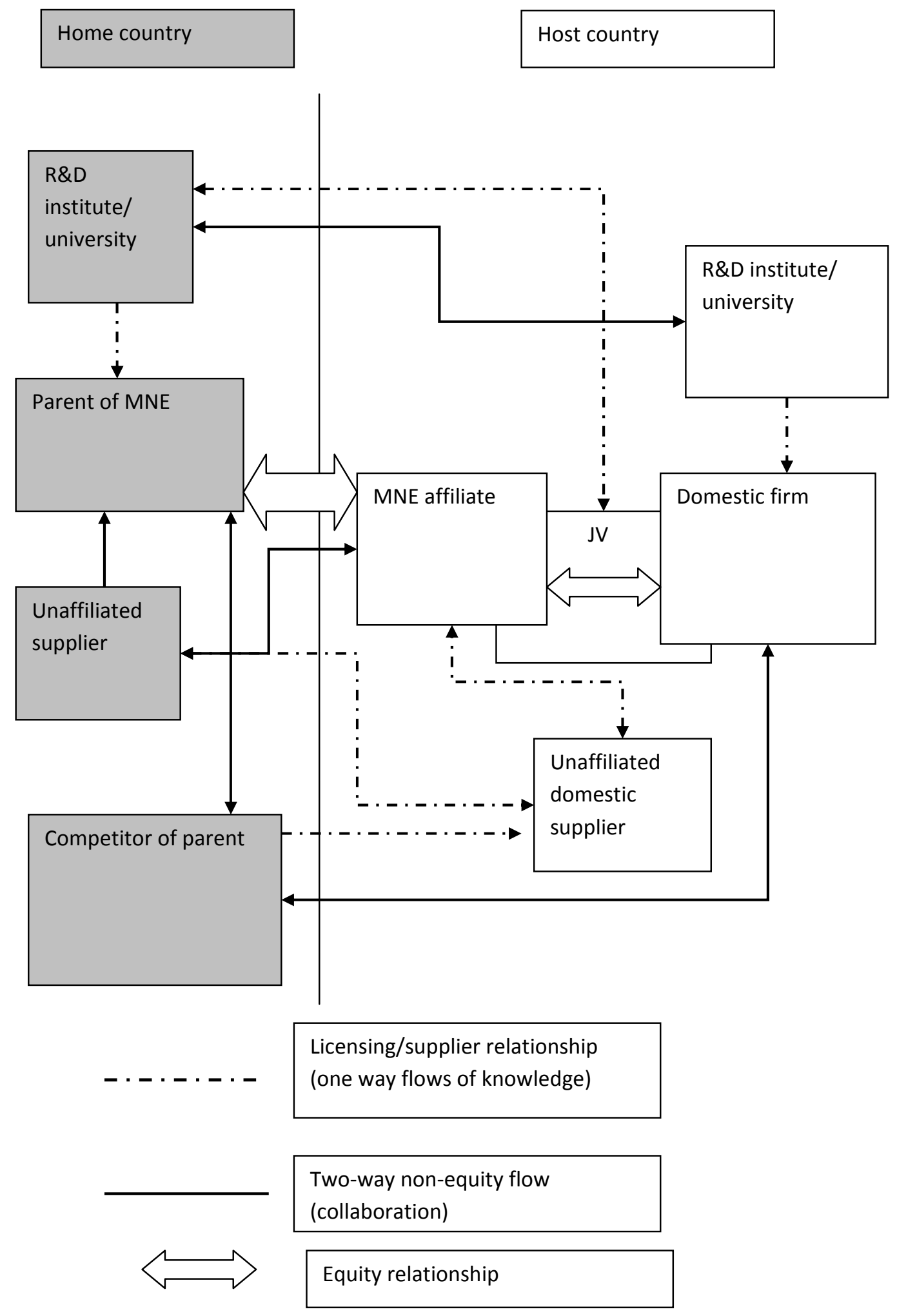

Figure 3: equity and non-equity cross border knowledge flows 


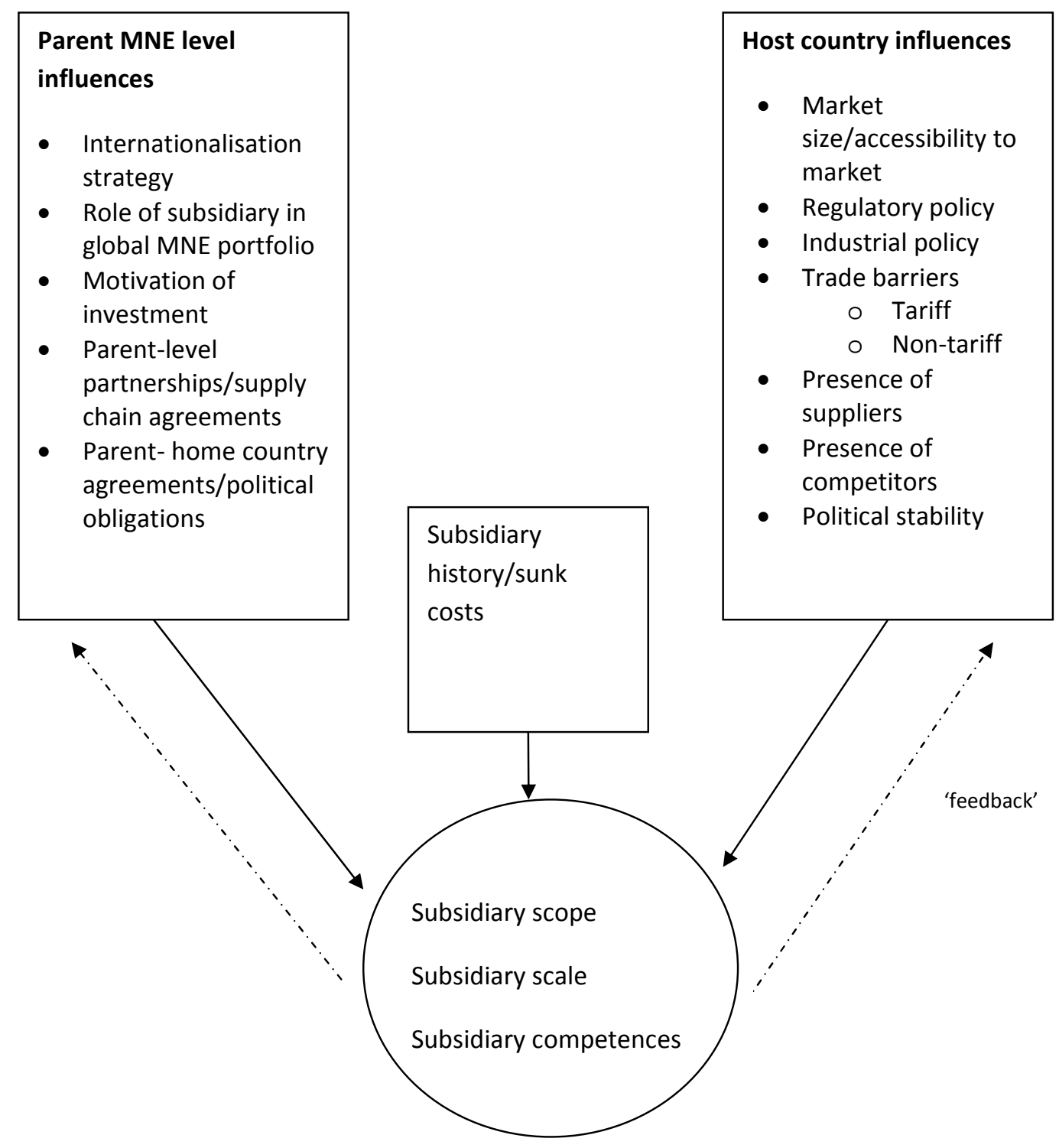

Figure 4: determinants of the competence, scope and scale of a foreign affiliate 


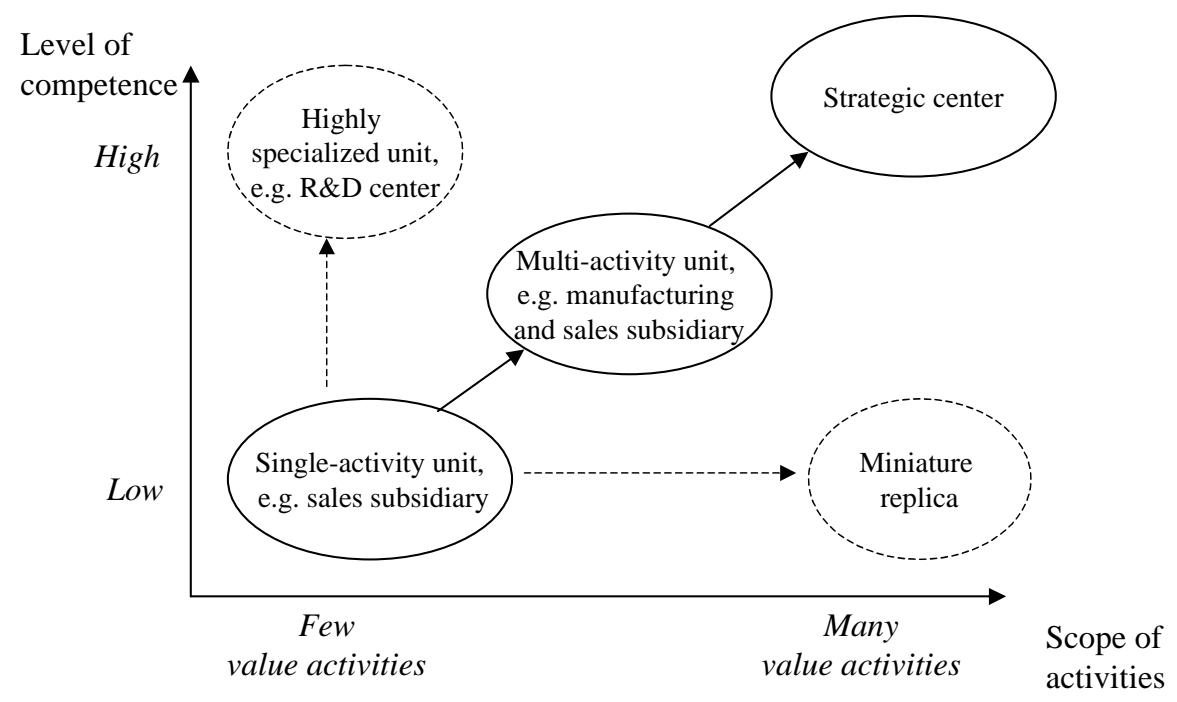

Source: Benito et al 2003

Figure 5Different types of subsidiaries, and their relationship to scope and competence levels. 
Figure 6: Graphical version of IDP

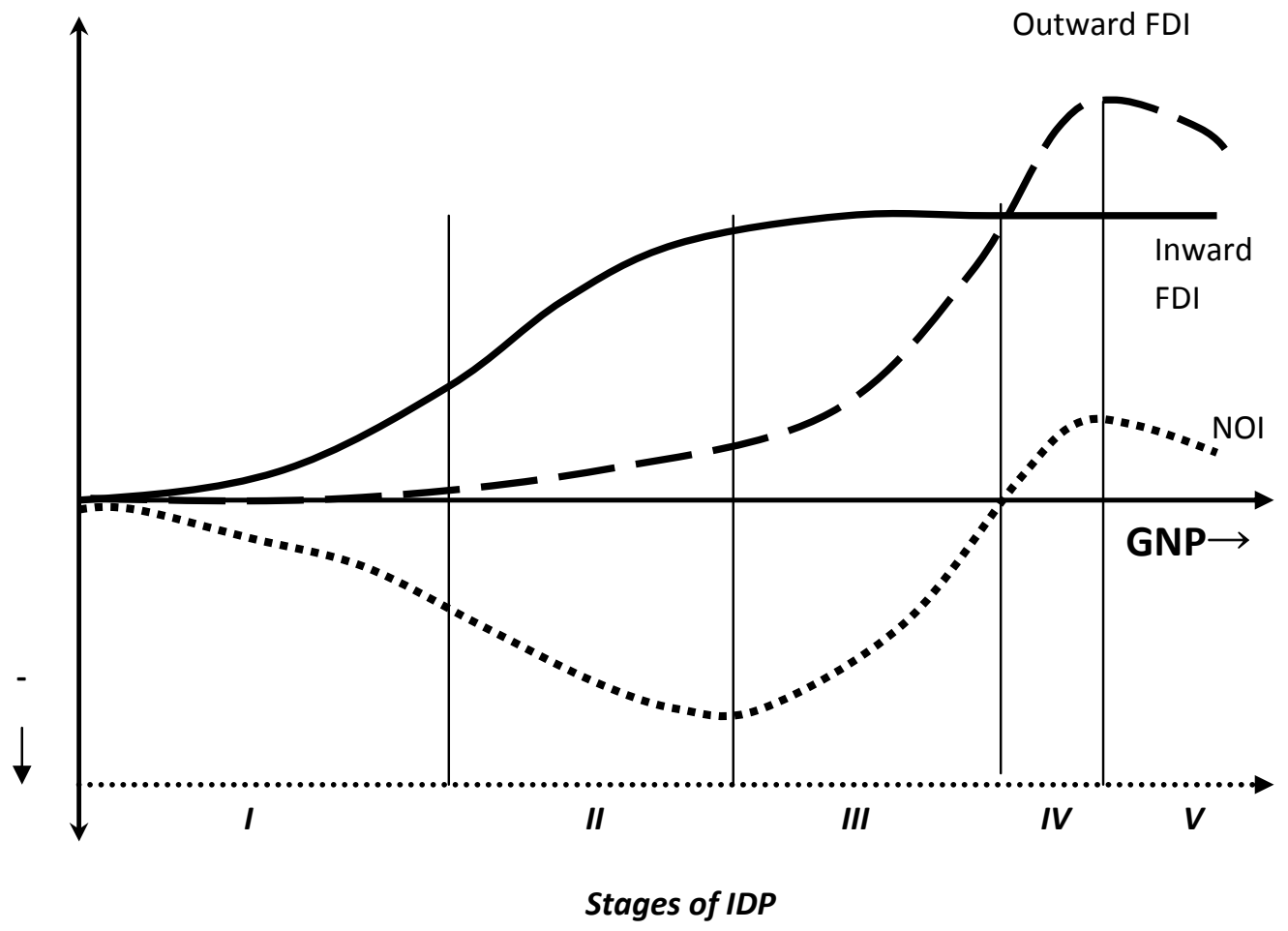

$\mathrm{NOI}=$ Net outward investment

(Remark: not drawn in scale; for illustrative purpose only) 
Table 1 Share of inward FDI in the developing world, by continent, and share of total from that continent (2011, US\$ millions)

\begin{tabular}{|l|l|l|}
\hline Africa & $\mathbf{5 6 9 5 5 9}$ & \\
\hline South Africa & 129890 & \\
\hline Egypt & 72612 & \\
\hline Nigeria & 69242 & \\
\hline Morocco & 46300 & \\
\hline Tunisia & 31414 & \\
\hline Share of 5 countries in total FDI to Africa & & $\mathbf{6 1 \%}$ \\
\hline & & \\
\hline Latin America & $\mathbf{2 , 0 4 8 , 1 0 1}$ & \\
\hline Brazil & 669,670 & \\
\hline Chile & 158,102 & \\
\hline Colombia & 95,668 & \\
\hline Argentina & 95,148 & \\
\hline Peru & 51,208 & \\
\hline $\begin{array}{l}\text { Share of 5 countries in total FDI to Latin } \\
\text { America }\end{array}$ & & $\mathbf{5 2 \%}$ \\
\hline & & \\
\hline Asia & $\mathbf{3 , 9 9 0 , 7 3 1}$ & \\
\hline China & 711,802 & \\
\hline Singapore & 518,625 & \\
\hline India & 201,724 & \\
\hline Indonesia & 173,064 & \\
\hline Thailand & 139,735 & \\
\hline Share of 5 countries in total FDI to Asia & & \\
\hline
\end{tabular}





\section{The UNU-MERIT WORKING Paper Series}

2013-01Effects of innovation on employment in Latin America by Gustavo Crespi and Ezequiel Tacsir

2013-02 Revisiting the porter hypothesis: An empirical analysis of green innovation for the Netherlands George van Leeuwen and Pierre Mohnen

2013-03 Impact of external knowledge acquisition strategies on innovation - A comparative study based on Dutch and Swiss panel data by Spyros Arvanitis, Boris Lokshin, Pierre Mohnen and Martin Wörter

2013-04 Interactive knowledge exchanges under complex social relations: A simulation modelRobin by Cowan and Anant Kamath

2013-05 Innovation systems framework: still useful in the new global context? by Michiko lizuka

2013-06 The importance of intrinsic and extrinsic motivation for measuring IQ by Lex Borghans, Huub Meijers and Bas ter Weel

2013-07 Firms' innovation capability-building paths and the nature of changes in learning mechanisms: Multiple case-study evidence from an emerging economy by Paulo N. Figueiredo, Marcela Cohen and Saulo Gomes

2013-08 A set of time series data labour market stocks and flows for the Netherlands 1980 to 2010 by Manuel Müllers, Joan Muysken and Erik de Regt

2013-09 Designing an optimal 'tech fix' path to global climate stability: R\&D in a multiphase climate policy framework by Adriaan van Zon and Paul A. David

2013-10 Complementarity between internal knowledge creation and external knowledge sourcing in developing countries by Jun Hou and Pierre Mohnen

2013-11Summarizing large spatial datasets: Spatial principal components and spatial canonical correlation by Samyukta Bhupathiraju, Bart Verspagen and Thomas Ziesemer

2013-12 Regional systems of innovation in the Arab region by Samia Satti Osman Mohamed Nour

2013-13 Development and social justice: Education, training and health in Sudan by Samia Satti Osman Mohamed Nour

2013-14 The economic importance and impacts of intellectual property rights (IPRs) in Sudan by Samia Satti Osman Mohamed Nour

2013-15 Overview of knowledge economy in the Arab region by Samia Satti Osman Mohamed Nour

2013-16 The importance (impacts) of knowledge at the macro-micro levels in the Arab Gulf countries by Samia Satti Osman Mohamed Nour

2013-17 Political determinants and impact analysis of using a cable system as a complement to an urban transport system by Diego Escobar-García, Francisco García-Orozco and Carlos Cadena-Gaitán

2013-18 Women entrepreneurs in the informal economy: Is formalization the only solution for business sustainability? By Shyama V. Ramani, Ajay Thutupalli, Tamas Medovarszki, Sutapa Chattopadhyay, Veena Ravichandran

2013-19 Heterogeneity in innovation strategies, evolving consumer preferences and market structure: An evolutionary multi-agent based modelling approach by Salih Çevikarslan 
2013-20 Optimal patent length and patent breadth in an R\&D driven market with evolving consumer preferences: An evolutionary multi-agent based modelling approach by Salih Çevikarslan

2013-21 Innovation and productivity: An update by Pierre Mohnen and Bronwyn H. Hall 2013-22 Fathers' use of parental leave. What do we know? by Nevena Zhelyazkova

2013-23 Eliciting Illegal migration rates through list randomization by David McKenzie and Melissa Siegel

2013-24 How do ICT firms in Turkey manage innovation? Diversity in expertise versus diversity in markets by Semih Akçomak, Erdal Akdeve and Derya Fındık

2013-25 Dynamic models of R\&D, innovation and productivity: Panel data evidence for Dutch and French manufacturing by Wladimir Raymond, Jacques Mairesse, Pierre Mohnen and Franz Palm

2013-26 Centre-based versus home-based childcare by Robert Bauchmüller

2013-27 Microeconometric evidence of financing frictions and innovative activity by Amaresh K Tiwari, Pierre Mohnen, Franz C Palm and Sybrand Schim van der Loeff

2013-28 Innovation for economic performance: The case of Latin American firms by Elena Arias Ortiz, Gustavo Crespi, Ezequiel Tacsir, Fernando Vargas and Pluvia Zuñiga

2013-29 Is money all? Financing versus knowledge and demand constraints to innovation Gabriele Pellegrino and Maria Savona

2013-30 Child deprivation in Ontario - A (less than perfect) comparison with Europe by Geranda Notten

2013-31 Measuring performance: does the assessment depend on the poverty proxy? by Geranda Notten

2013-32 How big is the impact of infrastructure on trade? Evidence from meta-analysis by Mehmet Güney Celbis, Peter Nijkamp and Jacques Poot

2013-33 Using a 'Systems' Perspective to Explain the Limits of 'New' Multinational Enterprises: the role of 'members-only' location advantages by Rajneesh Narula

2013-34 Foreign direct investment as a driver of industrial development: why is there so little evidence? by Rajneesh Narula 